\title{
Nitrogen Fertilization in Coastcross Pastures Associated with Forage Peanut on Nutritional Composition of Forage and Animal Performance
}

\author{
Ulysses Cecato ${ }^{1}$, José Augusto Nogueira Gomes ${ }^{1}$, Fabiola Cristine de Almeida Rego ${ }^{2}$, Elir de Oliveira ${ }^{3}$, \\ Wagner Paris ${ }^{4}$, Leandro Barbero ${ }^{5}$, Sandra Galbeiro ${ }^{6}$, Alexandre Lenzi ${ }^{7} \&$ Elias Nunes Martins ${ }^{1}$ \\ ${ }^{1}$ Department of Animal Science, State University of Maringá (UEM), Maringá, PR, Brazil \\ ${ }^{2}$ Department of Animal Science, University of North Paraná (UNOPAR), Arapongas, PR, Brazil \\ ${ }^{3}$ Agronomic Institute of Paraná (IAPAR), Campo Mourão, PR, Brazil \\ ${ }^{4}$ Federal Technological University of Paraná (UFTPR), Dois Vizinhos, PR, Brazil \\ ${ }^{5}$ Federal University of Uberlândia, Uberlândia, MG, Brazil \\ ${ }^{6}$ State University of Londrina (UEL), Londrina, PR, Brazil \\ ${ }^{7}$ Federal University of Santa Catarina (UFSC), Florianópolis, SC, Brazil \\ Correspondence: Fabiola Cristine de Almeida Rego, Department of Animal Science, University of North Paraná \\ (UNOPAR), Arapongas, PR 86708-000, Brazil. Tel: 55-43-3172-7570. E-mail: fabiolaregogrecco@gmail.com
}

Received: October 10, 2014 Accepted: November 7, 2014 Online Published: December 15, 2014

doi:10.5539/jas.v7n1p88 URL: http://dx.doi.org/10.5539/jas.v7n1p88

\begin{abstract}
The experiment was carried out at IAPAR, in Paranavaí-PR, from July 2002 to June 2007. A completely randomized design was used, with two replications and such treatments: Coastcross (Cynodon dactylon [L] Pers $\mathrm{Cv}$ Coastcross) + forage Peanut (Arachis pintoi Krapovickas and Gregori. Cv. Amarillo) $+200 \mathrm{~kg} \mathrm{ha}^{-1}$ of N; Coastcross + forage Peanut $+100 \mathrm{~kg} \mathrm{ha}^{-1}$ of N; Coastcross $+200 \mathrm{~kg} \mathrm{ha}^{-1}$ of N and Coastcross + forage Peanut. Cross heifers were used (Red angus $\times$ Nelore $\times$ Limousin), three of them as testers plus the regulator animals, with medium initial weight of $170 \mathrm{~kg}$, and management in continuous stocking and variable stocking rate. The pasture was maintained to a medium height of, approximately, $17 \mathrm{~cm}$. For the nutritional value evaluations (crude protein,CP, neutral detergent fibber, NDF, and in vitro dry matter digestibility, IVDMD) forage samples were collected, each 28 days, and separated in leaf blade, sheath+stem, dead material and plants of forage Peanut. The animal production was evaluated through the average daily gain (ADG, $\mathrm{kg} \mathrm{ha}^{-1} \mathrm{day}^{-1}$ ), weighted in fast each 28 days, stocking rate (AU, animal unit ha ${ }^{-1}$; being that the animal unit corresponds to $450 \mathrm{~kg}$ of live weight) and body weight gain (BWG, $\mathrm{kg} \mathrm{ha}^{-1}$ ). Pastures of grasses and legumes with no $\mathrm{N}$ fertilization have a lower nutritional composition than fertilized pastures. Forage nutritional composition and animal performance vary according to the conditions each year, thereby affecting stocking rate and live weight gain.
\end{abstract}

Keywords: animal performance, forage mass production, grazing cattle, stocking rate

\section{Introduction}

Animal performance on pasture systems depends on forage intake and quality, as well as on management, fertilization, and intrinsic factors of the forage. Fertilization is important in the pasture production process because having an adequate amount of nutrients, mainly nitrogen, results in greater forage productivity and therefore greater animal performance (Fagundes et al., 2006). However, large amounts of $\mathrm{N}$ fertilization in the pasture can also lead to increased production costs and may contribute to environmental contamination (Primavesi et al., 2006).

Thus, some researchers have studied the benefits of grasses and legumes on pastures (Rego et al., 2006) and animal productivity (Paris et al., 2009). Moreover, this type of pasture management represents an alternative, low cost method of reducing degradation (Aroeira et al., 2005) due to the $\mathrm{N}$ supply in the production system.

Studies regarding forage nutritional composition are essential in grazing animal production systems because they can provide important information about limiting factors related to the intake of nutrients and therefore, provide information about factors affecting animal production (Brâncio et al., 2002). Thus, it is possible to improve productivity greater than $1.000 \mathrm{~kg}$ live weight $\mathrm{ha}^{-1}$ year $^{-1}$ with management techniques and an adequate forage 
allowance that would increase the SR (Paris et al., 2009).

The grasses of the Cynodon genus have been intensively studied and used in Brazil due to some advantages presented by this genus such as nutritional value, productive potential, fertilization response, adaptation to different environments, and flexibility of use (Vilela et al., 2006).

Therefore, this experiment was conducted to evaluate forage quality and animal performance in Coastcross pastures associated with forage peanut, with or without $\mathrm{N}$ fertilization, when continuously stocked for a 5 -year period.

\section{Materials and Methods}

This experiment was conducted at the Experimental Station of IAPAR, in Paranavaí - Parana State, Brazil, located at $23^{\circ} 05^{\prime} \mathrm{S}, 52^{\circ} 26^{\prime} \mathrm{W}$ and with an average altitude of $480 \mathrm{~m}$. The predominant climate is a meso thermal humid subtropical according to the Köeppen classification (IAPAR, 1994). The climate data was collected over 5 years and it is presented in Figure 1.

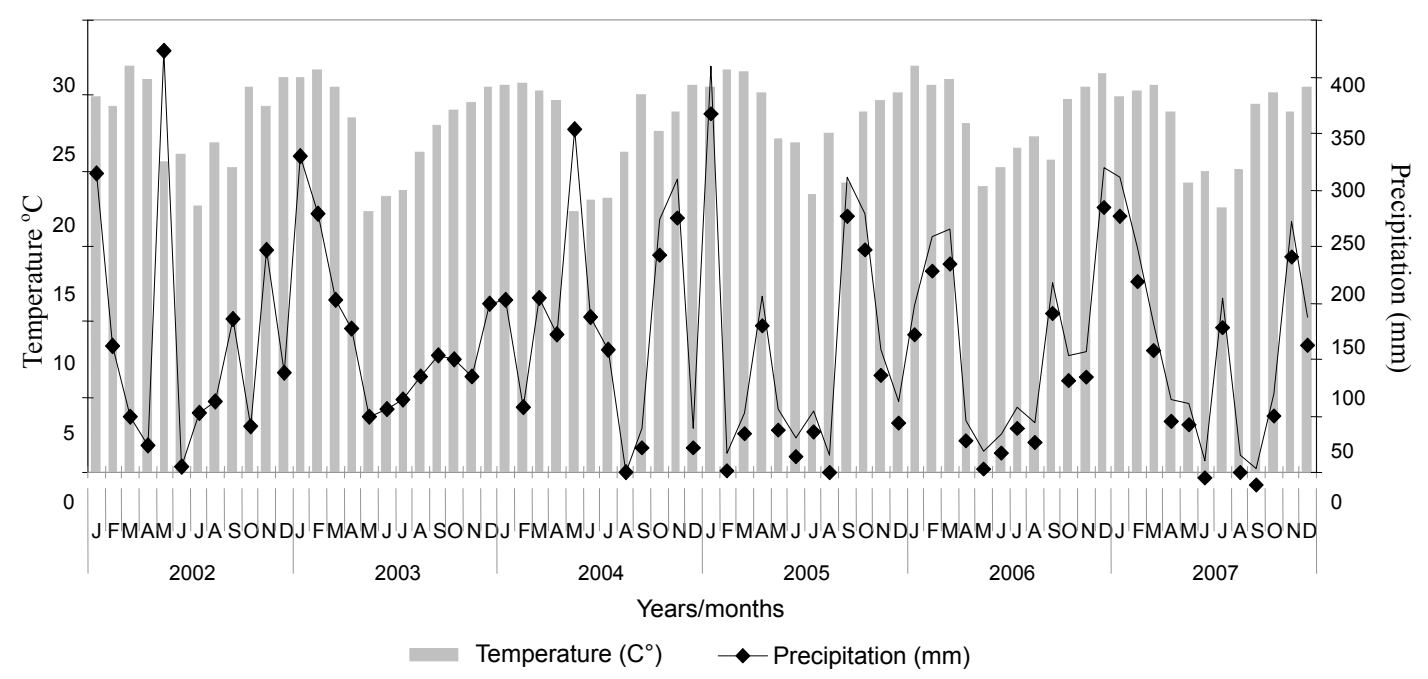

Figure 1. Climatic conditions observed during the experimental period (January of 2002 to June of 2007)

The soil in the experimental area is classified as Dystrophic Oxisol (EMBRAPA, 1999) and contains 88\% sand, $2 \%$ silt, and $10 \%$ clay with a low $\mathrm{pH}$, low cation exchange capacity, and low organic matter and phosphorus content (IAPAR, 1999). Soil samples were collected at the beginning of each year for each experimental unit at a 0-20 cm depth. Sample analyses are presented in Table 1.

The experimental period took place from July 2002 to June 2007 in an experimental area with Coastcross pastures (Cynodon dactylon [L] Pers Cv Coastcross) associated with forage peanut (Arachis pintoi Krapovickas and Gregori. Cv. Amarillo) and under continuously stocked grazing conditions. The total area of 5.3 ha was subdivided into eight paddocks with an average area of $0.66 \mathrm{ha}$ each. The experimental design was completely randomized and consisted of two repetitions and four treatments: Coastcross + Forage peanut $+200 \mathrm{~kg} \mathrm{ha}^{-1}$ of N (CA200), Coastcross + Forage peanut $+100 \mathrm{~kg} \mathrm{ha}^{-1}$ of N (CA100), Coastcross $+200 \mathrm{~kg} \mathrm{ha}^{-1}$ of N (C200), and Coastcross + Forage peanut (CA).

The nitrogen and potassium fertilizers were administered annually and divided into four periods (November to April), with ammonium nitrate as the $\mathrm{N}$ source and potassium chloride as the $\mathrm{K}$ source. Potassium fertilization was provided to raise $\mathrm{K}$ saturation close to $4 \%$ CEC (cation exchange capacity) Superphosphate was used together in the first period $\mathrm{N}$ and $\mathrm{K}$ fertilization to increase phosphorus content approximately to $15 \mathrm{mg} \mathrm{dm}^{-3}$. A commercial fertilizer BR12 (Calcium - 7.1\%; Sulfur - 5.7\%, Boron - 1.8\%; Copper - 0.8\%, Manganese - 2.0\%; Molybdenum - 1\%; Zinc - 9.0\%) was used as a micronutrient mineral source and was applied at $50 \mathrm{~kg} \mathrm{ha}^{-1}$; both applied in a single time. All fertilizers were applied manually.

The pasture was managed under continuous stocking but with variable stocking. Three tester heifers as well as regulator heifers were utilized to maintain the desired height of the pasture. Crossbred heifers (Red Angus $\times$ 
Nellore $\times$ Limousin) with an initial age of eight months and an average initial body weight of $170 \mathrm{~kg}$ were used. These animals were replaced with new animals of the same standards each winter. The pasture was maintained at an average height of 16 to $18 \mathrm{~cm}$ using a technique called "put and take" (Mott and Lucas, 1952). Fifty height measurements were randomly performed in all experimental units twice a week.

Forage samples were collected each 28-d period to evaluate forage nutritional composition. Afterwards, a morphological separation was conducted to separate leaf blades (LB), stem + sheath (SS), and dead material (DEM) from Coastcross and forage peanuts (FP). After the morphological separation, samples were dried in an air forced oven $\left(55^{\circ} \mathrm{C}\right.$ for $\left.72 \mathrm{~h}\right)$, then ground in a knife mill $(1 \mathrm{~mm}$ sieve) prior to analyzing the samples. Chemical analyses were conducted on LB, SS and whole plants in order to evaluate their nutritional composition. Dry matter (DM) and crude protein (CP) contents were determined according to AOAC (1990), while neutral detergent fiber (NDF) was determined according to Van Soest (1991).In vitro digestibility of dry matter (IVDDM) was determined according to Tylley and Terry (1963), adapted for use in artificial rumens according to Holden (1999), and developed by Ankon®.

Table 1. Results of soil analysis of experimental area, 2002 to 2006

\begin{tabular}{|c|c|c|c|c|c|c|c|c|c|c|c|c|}
\hline \multirow{2}{*}{ Year } & \multirow{2}{*}{ Treat } & \multirow{2}{*}{$\frac{\mathrm{mg} / \mathrm{dm}^{3}}{\mathrm{P}}$} & \multicolumn{3}{|c|}{$\mathrm{mg} / \mathrm{dm}^{3}$} & \multicolumn{6}{|c|}{ cmolc $/ \mathrm{dm}^{3}$ soil } & \multirow{2}{*}{$\begin{array}{l}\% \\
\mathrm{~V}\end{array}$} \\
\hline & & & $\mathrm{C}$ & $\mathrm{pH}$ & $\mathrm{Al}$ & $\mathrm{H}+\mathrm{Al}$ & $\mathrm{Ca}$ & $\mathrm{Mg}$ & $\mathrm{K}$ & $\mathrm{S}$ & $\mathrm{T}$ & \\
\hline 2002 & Área total & 10,1 & 6,9 & 5 & 0,02 & & 1,27 & 0,69 & 0,16 & 2,12 & 2,14 & 42 \\
\hline \multirow[t]{4}{*}{2003} & CA200 & 5,67 & 9,93 & 4,5 & 0,11 & 3,00 & 1,15 & 0,70 & 0,18 & 2,03 & 5,03 & 39,88 \\
\hline & CA100 & 5,62 & 8,98 & 4,52 & 0,14 & 2,83 & 1,1 & 0,81 & 0,11 & 2,02 & 4,85 & 41,3 \\
\hline & $\mathrm{C} 200$ & 4,42 & 8,62 & 4,35 & 0,16 & 3,18 & 0,98 & 0,63 & 0,14 & 1,75 & 4,93 & 35,32 \\
\hline & $\mathrm{CA}$ & 9,87 & 10,16 & 4,95 & 0,04 & 2,59 & 1,34 & 1,01 & 0,17 & 2,52 & 5,11 & 48,97 \\
\hline \multirow[t]{4}{*}{2004} & CA200 & 6,55 & 6,05 & 4,45 & 0,13 & 2,94 & 0,98 & 0,57 & 0,13 & 1,68 & 4,62 & 36,24 \\
\hline & CA100 & 8,00 & 7,11 & 4,90 & 0,05 & 2,64 & 1,21 & 0,84 & 0,11 & 2,16 & 4,79 & 44,64 \\
\hline & $\mathrm{C} 200$ & 6,10 & 5,36 & 4,60 & 0,09 & 2,74 & 0,92 & 0,61 & 0,13 & 1,66 & 4,40 & 37,76 \\
\hline & $\mathrm{CA}$ & 10,45 & 7,38 & 5,35 & 0,00 & 2,35 & 1,59 & 0,97 & 0,18 & 2,73 & 5,08 & 53,49 \\
\hline \multirow[t]{4}{*}{2005} & CA200 & 8,44 & 7,48 & 4,50 & 0,17 & 3,64 & 0,83 & 0,49 & 0,18 & 1,51 & 5,13 & 28,99 \\
\hline & CA100 & 9,15 & 7,35 & 4,74 & 0,08 & 3,24 & 0,87 & 0,57 & 0,29 & 1,71 & 4,95 & 34,29 \\
\hline & $\mathrm{C} 200$ & 9,99 & 7,74 & 4,64 & 0,11 & 3,37 & 0,80 & 0,54 & 0,23 & 1,56 & 4,92 & 31,41 \\
\hline & $\mathrm{CA}$ & 10,22 & 8,21 & 5,32 & 0,00 & 2,74 & 1,30 & 0,94 & 0,27 & 2,49 & 5,23 & 47,05 \\
\hline \multirow[t]{4}{*}{2006} & CA200 & 15,50 & 9,20 & 5,00 & 0,30 & 2,90 & 1,40 & 1,10 & 0,20 & 2,70 & 5,60 & 47,60 \\
\hline & CA100 & 13,70 & 9,60 & 5,40 & 0,00 & 2,30 & 1,70 & 1,20 & 0,20 & 3,10 & 5,50 & 57,00 \\
\hline & C200 & 17,50 & 10,50 & 5,00 & 0,00 & 2,80 & 1,30 & 1,20 & 0,30 & 2,80 & 5,60 & 49,50 \\
\hline & $\mathrm{CA}$ & 17,60 & 9,90 & 5,60 & 0,00 & 2,20 & 2,00 & 1,30 & 0,30 & 3,60 & 5,90 & 61,10 \\
\hline
\end{tabular}

CA200 $=$ Coastcross + Forage peanut $+200 \mathrm{~kg} \mathrm{of} \mathrm{N} \mathrm{ha}^{-1}$ per year; CA100 $=$ Coastcross + Forage peanut +100 $\mathrm{kg}$ of $\mathrm{N} \mathrm{ha}^{-1}$ per year; $\mathrm{C} 200=$ Coastcross $+200 \mathrm{~kg}$ of $\mathrm{N} \mathrm{ha}^{-1}$ per year; $\mathrm{CA}=$ Coastcross + Forage peanut.

The animals were weighed every $28 \mathrm{~d}$ after an eight-hour fasting period (Hughes, 1976). The average daily gain (ADG, $\mathrm{kg}_{\text {animal }}{ }^{-1} \mathrm{~d}^{-1}$ ) was estimated by comparing the weight of the tester heifers at the beginning and the end of the experiment, then dividing this difference by the number of days that the animals were kept on the pasture. This procedure was conducted for each year. The number of animals $\mathrm{d}^{-1} \mathrm{ha}^{-1}$ (NAD) was obtained by multiplying the number of animals in each paddock by the number of days that the animals were kept in each paddock, then divided by paddock area. Body weight gain (BWG, $\mathrm{kg} \mathrm{ha}^{-1}$ ) was obtained by multiplying ADG by NAD for each year. Stocking rate $\left(\mathrm{AU} \mathrm{ha}^{-1}\right)$ was calculated by adding the average body weight regulator heifers and tester heifers, multiplying this sum by the number of days that these animals were kept on pasture, and then dividing this by the number of days in each experimental period.

The experimental variables were analyzed with the Statistical Analysis Systems Institute (SAS, 2006). The 
statistical model used was as follows: $Y_{i j k}=\mu+T_{i}+Y_{j}+T_{i j}+e_{i j k}$; were $Y_{i j k}=$ observed value in the paddock where treatment $i$ was evaluated under year $j$ effect; $\mu=$ overall mean; $T_{i}=$ treatment effect with $i$ varying from 1 to $4 ; Y_{j}=$ year effect with $\mathrm{j}$ varying from 1 to $5 ; \mathrm{TA}_{\mathrm{ij}}=$ interaction effect between treatment $\mathrm{i}$ and year $\mathrm{j} ; \mathrm{e}_{\mathrm{ijk}}=$ random error associated with each observation. The effects of year and treatments were evaluated using regression analyses.

\section{Results and Discussion}

There was a significant difference $(P<0.05)$ of $C P$ in leaf blades $(C P L)$ among treatments and years (Figure 2). Crude protein in leaf blades from CA200 demonstrated a quartic effect, while the CA100 and C200 treatments demonstrated a cubic effect over the years. The lowest CPL content was observed in 2002, and the greatest CPL values were obtained in 2003 and 2004. The increase of CPL in 2003 and 2004 may be explained by the better climate conditions in this period (Figure 1) and the N fertilization. Hejcman et al. (2012) observed positive effects of $\mathrm{N}$ fertilization on increasing forage biomass for Dactilys glomerata and Festuca arundinacea.

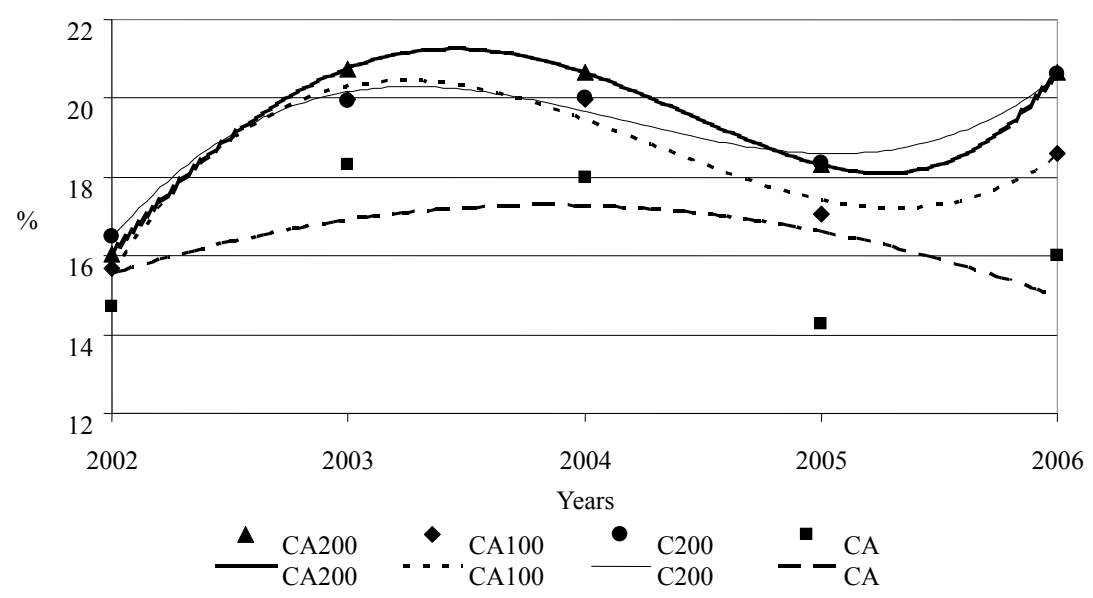

Figure 2. Crude protein of leaf blade (CPL) in Coastcross pasture mixed with Forage peanut, with or without nitrogen fertilization, for five years. Regression equation and $\mathrm{R}^{2}$; CA200 $\left(y=20,25-4,70 \mathrm{x}-3,99 \mathrm{x}^{2}-1,46 \mathrm{x}^{3}-0,85\right.$ $\mathrm{x}^{4}+0,23$ and 1,00); CA100, C200 (y=18,98-1,78 $\mathrm{x}-0,45 \mathrm{x}^{2}+0,66 \mathrm{x}^{3}+0,12$ and 0,97$)$ and CA $(y=19,66+0,26$ $\mathrm{x}-0,79 \mathrm{x}^{2}+0,180$ and 0,90$)$

The lowest CPL value observed in 2002 may be due to previous management of the pasture, as the pasture was kept at a higher height than the height maintained in the study; in addition 2002 was the year that the experiment was first implemented. Similarly, we observed a lower CPL value in 2005, but this occurred because biomass production was greater in this year, which can cause a dilution effect similar to the one observed in 2002 (Rocha et al., 2002). Paciullo et al. (2008) evaluated elephant grass under grazing conditions during three consecutive years and verified the effect of year on CP content; however, CP content was not associated with forage productivity during these years.

The pasture subjected to CA treatment demonstrated a quadratic effect on CPL and had the lowest CPL content. Sousa et al. (2010) evaluated $\mathrm{N}$ doses on chemical composition in Tanzania grass and observed similar results to those of our current study. However, pasture productivity and nutrient content showed improvement sin these associations even without $\mathrm{N}$ fertilization. Wang et al. (2010) recognized a change in the association between legumes and grasses in monoculture, and realized that the inclusion of legumes in grass pastures can be considered an alternative nitrogen source.

In CA200 and CA treatments, crude protein of stems (CPS) demonstrated a quartic effect and differed $(P<0.05)$ over the years (Figure 3), while CA100 and C200 presented with a cubic effect and were similar over the years. Both leaf blades and pastures with the greatest $\mathrm{N}$ content achieved the best results in 2003 and 2004.Correa et al. (2007) observed similar results using Coastcross grass with $\mathrm{N}$ fertilization. The crude protein of stem sin this study was greater than that observed by Prohmann et al. (2004), who described a 6.7\% CPS using the same grass as the current study under continuous stocking conditions.

The crude protein of the whole forage peanut plant (CPFP) demonstrated a quartic effect over the years (Figure 4). Moreover, $\mathrm{N}$ fertilization did not significantly influence CPP $(P>0.05)$. Valentim et al. (2003) studied 
different forage peanut cultivars and accessions and observed CPFP values ranging from 17.9 to $21.7 \%$.

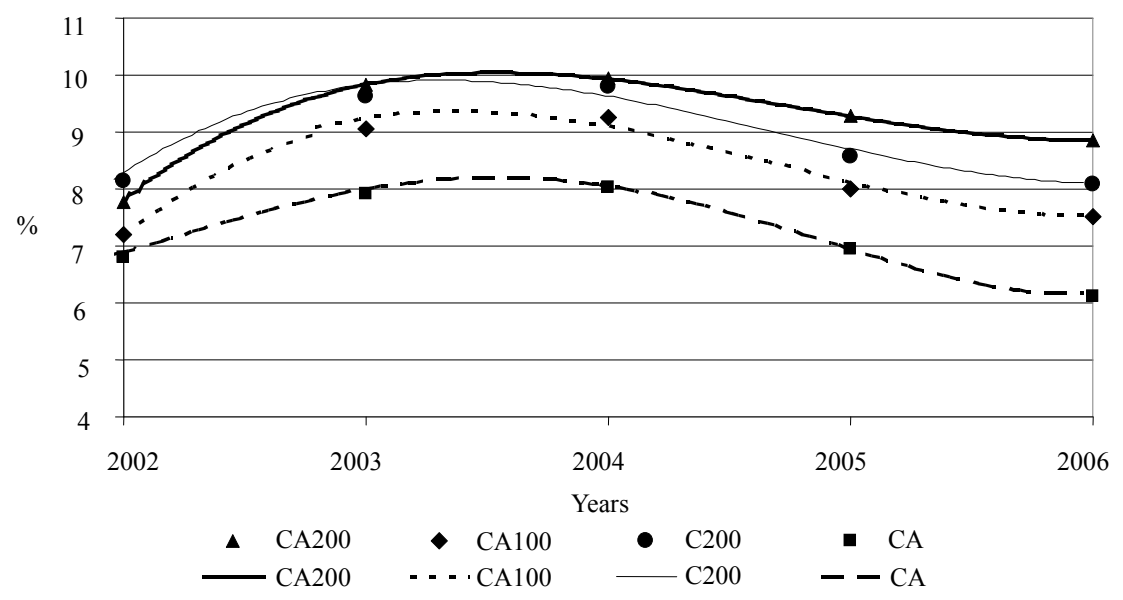

Figure 3. Crude protein of stem (CPS) in Coastcross pasture mixed with Forage peanut, with or without nitrogen fertilization, for five years. Regression equation and $\mathrm{R}^{2}-\mathrm{CA} 200\left(\mathrm{y}=9,53-2,01 \mathrm{x}-1,92 \mathrm{x}^{2}+0,57 \mathrm{x}^{3}+0,38 \mathrm{x}^{4}+0,12\right.$ and 1,00); CA100, C200 (y=9,09-0,72 x-0,41 $\mathrm{x}^{2}+0,19 \mathrm{x}^{3}+6,37$ and 0,98$)$ and $\mathrm{CA}\left(\mathrm{y}=8,67+0,96 \mathrm{x}+0,90 \mathrm{x}^{2}-0,28\right.$ $x^{3}-0,32 x^{4}+0,12$ and 1,00$)$

In addition to the $\mathrm{CP}$ content observed in the association between grasses and legumes, which has a huge effect on pasture components and therefore on animal performance, there are also other factors that can impact pasture quality and animal performance. Rego et al. (2006) evaluated the association between Marandu (Brachiaria brizantha cv. Marandu) grass and forage peanut and reported that besides the high CP content present in the legume, other important factors also influenced animal intake such as height of the pasture, biomass of leaves and grasses, and total biomass of legumes.

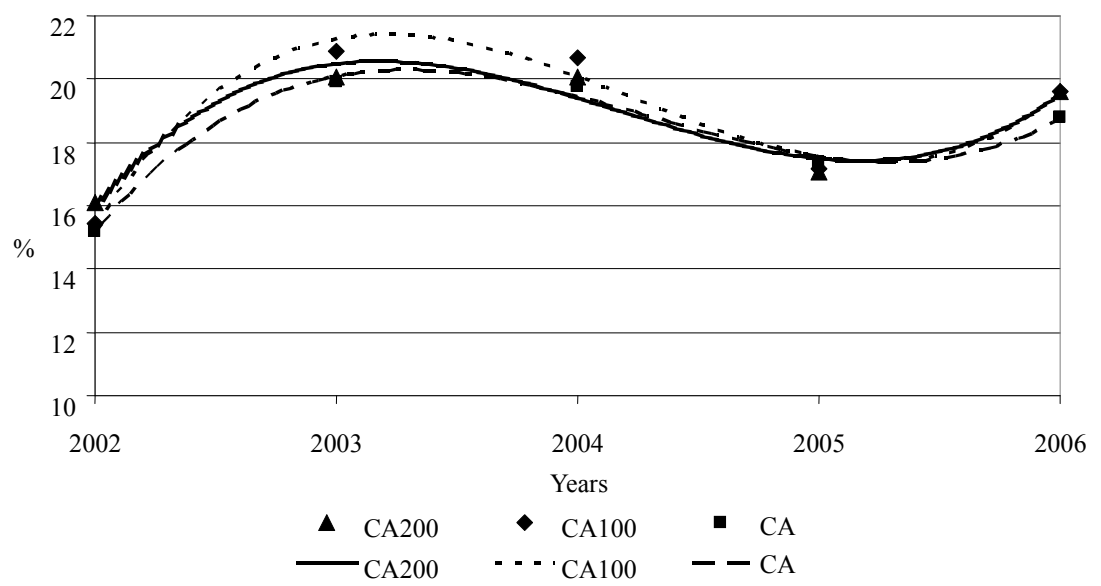

Figure 4. Crude protein of Pinto peanut (CPA), with or without nitrogen fertilization, for five years. Regression equation and $R^{2}-C A 200, C A 100, C 200$ e CA $\left(y=10,98+5,64 x-0,59 x^{2}-0,19 x^{3}+0,03 x^{4}+0,003\right.$ and 0,89$)$

The neutral detergent fiber content of leaf blades (NDFL) and of stems (NDFS) had a quartic effect over the years (Figures 5 and 6, respectively) with no difference observed among the treatments. 


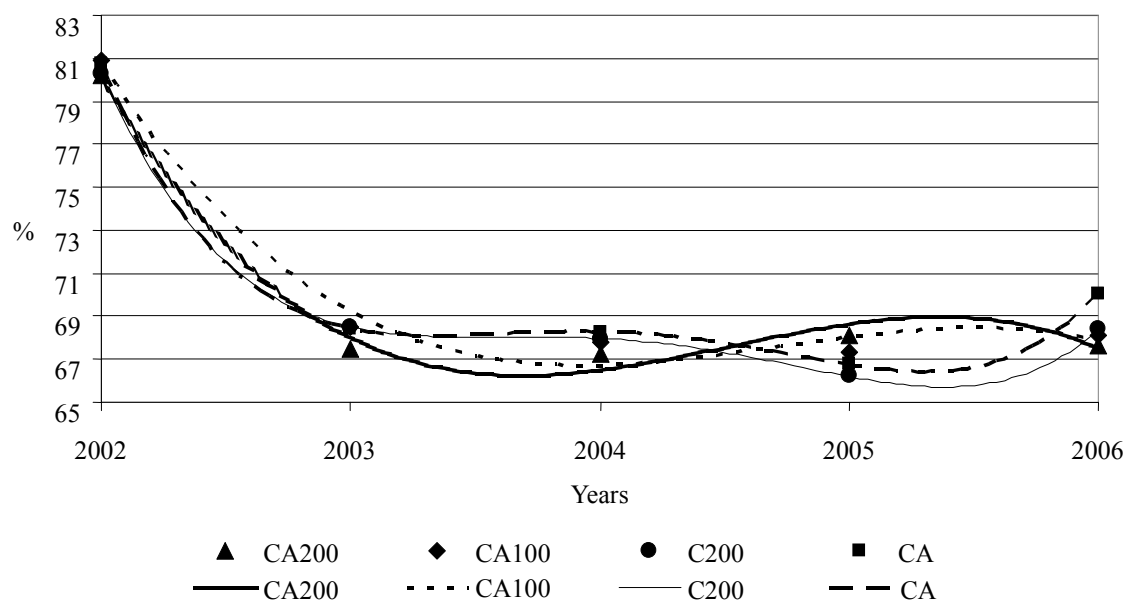

Figure 5. Neutral detergent fiber of leaf blade (NDFL) in Coastcross pasture mixed with Forage peanut, with or without nitrogen fertilization, for five years. Regression equation and $\mathrm{R}^{2} \mathrm{CA} 200, \mathrm{CA} 100, \mathrm{C} 200$ and CA (y = $67,84+0,24 x-0,79 x^{2}-0,81 x^{3}+0,62 x^{4}+0,13$ and 1,00$)$

The neutral detergent fiber content of leaf blades and NDFS were greater in 2002 and 2006 than in 2003 to 2005.These greater values for NDF in 2002 are due to the previously described pasture management, and to the fact that the leaf blades and stems were older and therefore responsible for increasing NDF content in the pasture. Unlike CP, NDF content did not vary over the years, which indicates a great stability in DM content over the years. Pitman (2012) evaluated frequently cut Paspalum notatum that was fertilized with $\mathrm{N}$ over three consecutive years, and did not observe any significant variation in NDF content over the years.

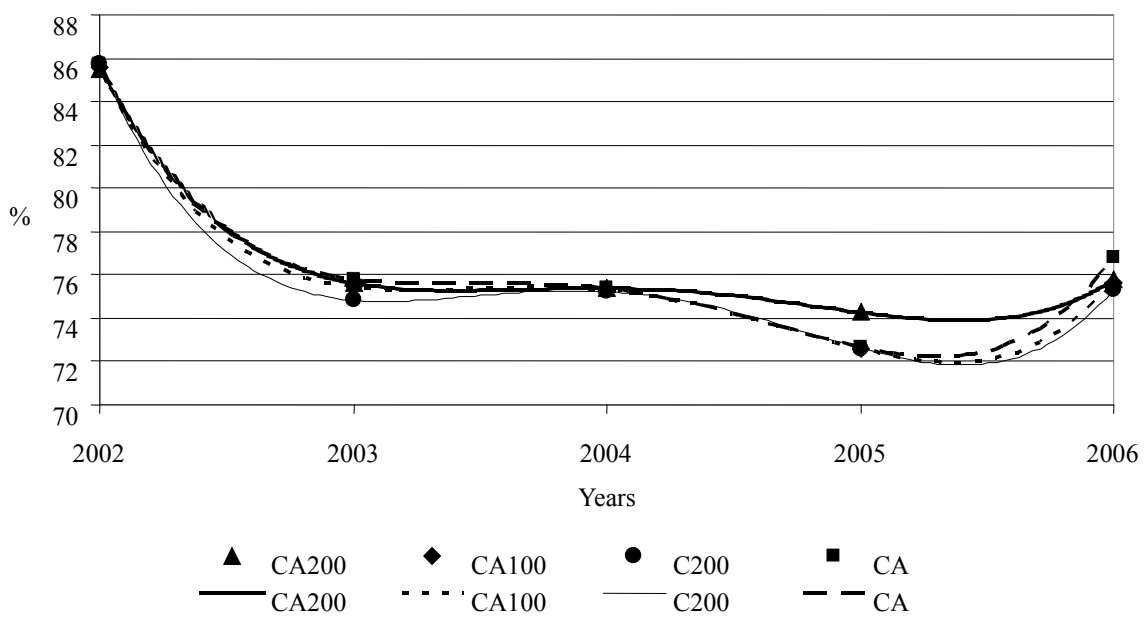

Figure 6. Neutral detergent fiber of stem fractions (NDFS) in Coastcross pasture mixed with Forage peanut, with or without nitrogen fertilization, for five years. Regression equation and $\mathrm{R}^{2}$ - CA200, CA100, C200 and CA (y = $75,32-0,78 \mathrm{x}-0,19 \mathrm{x}^{2}-0,41 \mathrm{x}^{3}+0,82 \mathrm{x}^{4}+8,11$ and 1,00$)$

Nitrogen fertilization did not affect either NDFL or NDFS, which may be explained by the uniform maintenance of pasture height, as the pasture fraction remained more stable during all experimental periods. Some studies (Barbero et al., 2010; Rocha et al., 2001) evaluated Coastcross grass and forage peanut and suggested that the $\mathrm{NDF}$ content was not influenced by $\mathrm{N}$ fertilization.

Neutral detergent fiber content of forage peanut (NDFP) demonstrated a quadratic effect over the years, but no difference was observed among treatments (Figure 7). Thus, we can infer that legumes have the capacity to maintain their quality after they have been utilized (Viana et al., 2000).

In vitro digestibility of leaf blades (IVDL) and stems (IVDS) illustrated a quartic effect over the years, and a 
difference was observed among treatments for stems (Figures 8 and 9 respectively). Pitman (2012) relayed that Paspalum notatum is also responsive to $\mathrm{N}$ fertilization, and that greater $\mathrm{N}$ doses resulted in the greatest $\mathrm{CP}$ and IVDDM content of the whole plant. In vitro digestibility of leaf blades and IVDS content were greater in 2002 to 2005 , which can be attributed to the climate, pasture management, and NDF content observed in this period. In vitro digestibility of stems revealed similar values to those observed for IVDL in 2005 and 2006 (Figure 9). This result suggests that if a grass is adequately managed under favorable climate conditions, the grass will be of good quality in all components of the plant. Fisher et al. (1991) also verified a similar result in IVDL and IVDS for Coastcross grass managed under continuous grazing conditions. Paris et al. (2009) in a similar study, evaluated N fertilization and observed greater nutrient digestibility values, while Rocha et al. (2001) found that the quality of the genus Cynodon grass is due to its high nutrient digestibility.

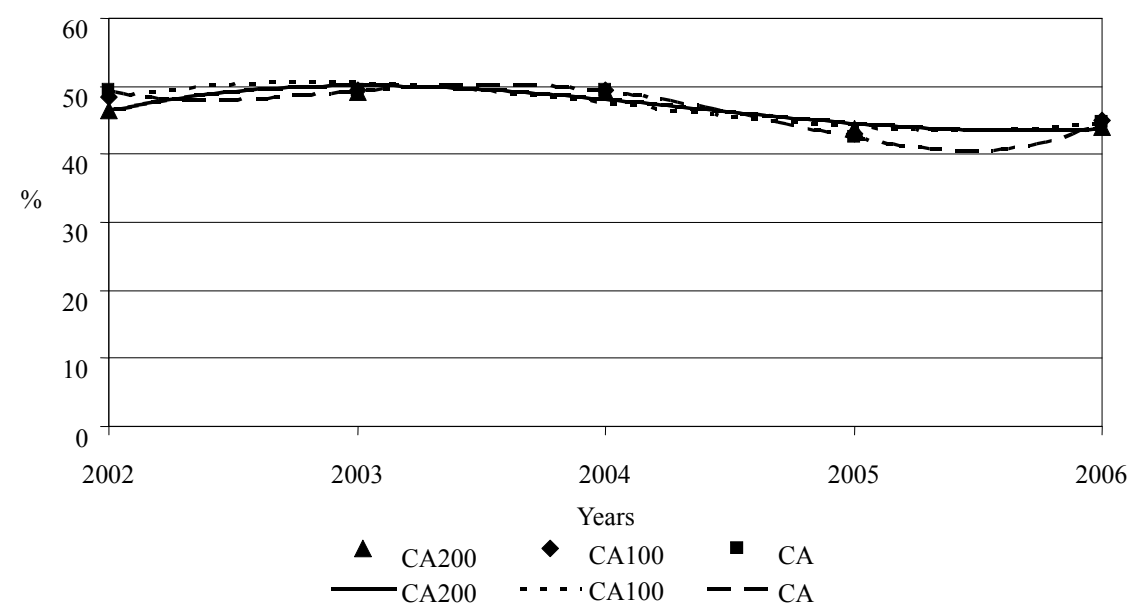

Figure 7. Neutral detergent fiber of Forage peanut whole plant (NDFP) in mixed pasture with Coastcross, with or without nitrogen fertilization, for five year. Regression equation and $\mathrm{R}^{2}$ - CA200, CA100, C200 e CA (y = $49,33-3,88 x-3,94 x^{2}+0,75 x^{3}+0,80 x^{4}+0,20$ and 1,00$)$

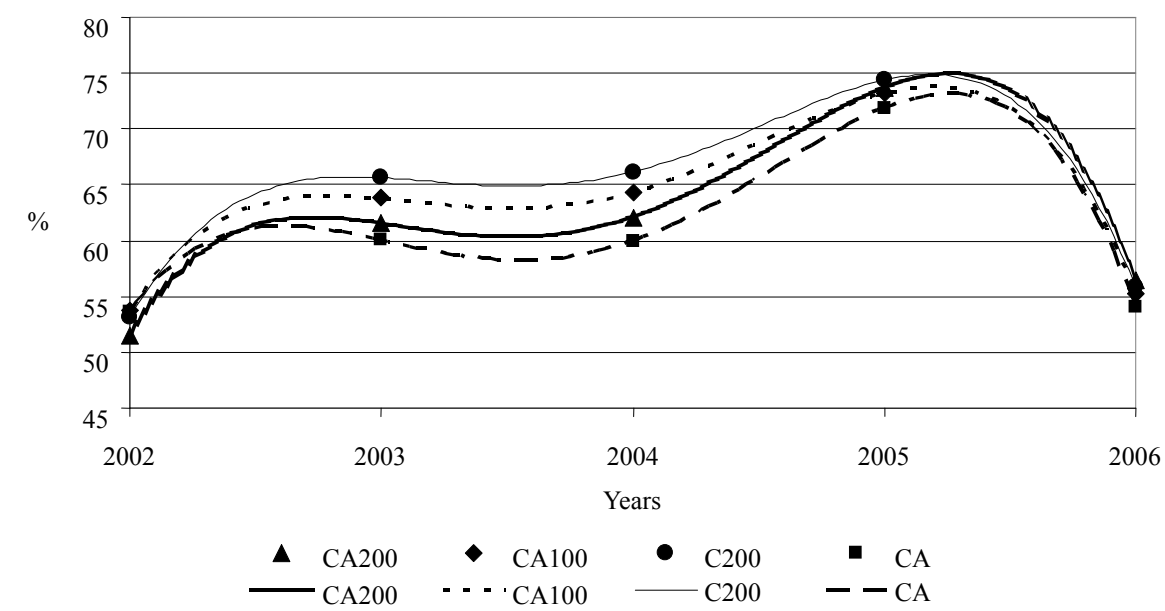

Figure 8. Dry matter in vitro digestibility of leaf blade (IVDL) in Coastcross pasture mixed with Forage peanut, with or without nitrogen fertilization, for five years. Regression equation and $\mathrm{R}^{2}$ - CA200, CA100, C200 e CA (y $=63,15+6,82 \mathrm{x}+7,62 \mathrm{x}^{2}-1,56 \mathrm{x}^{3}-2,38 \mathrm{x}^{4}+0,26$ and 1,00$)$ 


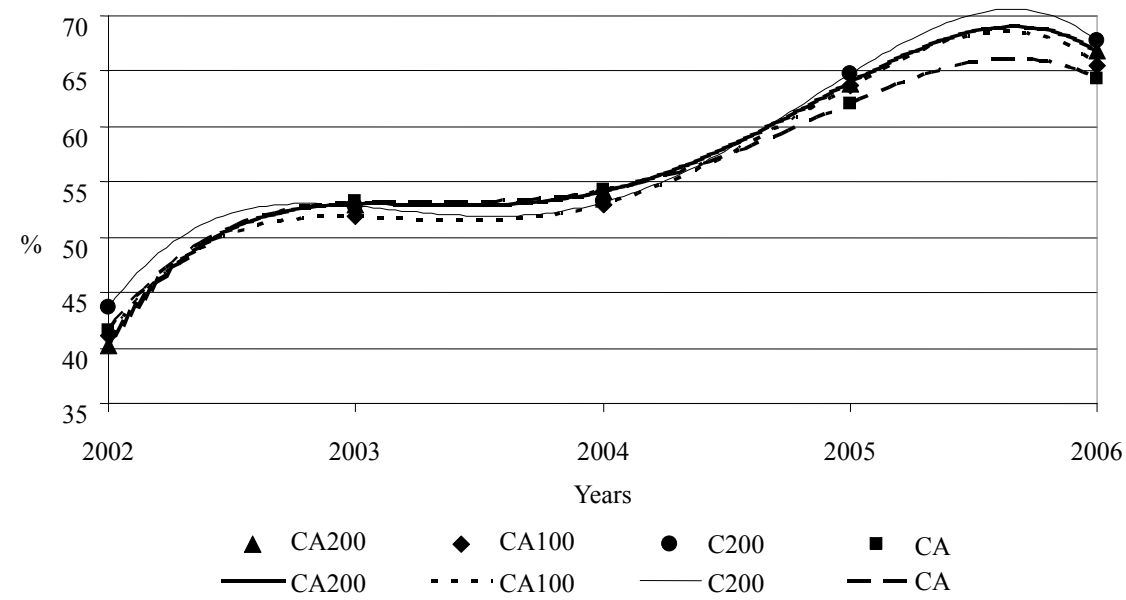

Figure 9. Dry matter in vitro digestibility of stem fractions (IVDS) in Coastcross pasture mixed with Forage peanut, with or without nitrogen fertilization, for five years. Regression equation and $\mathrm{R}^{2}$ - CA200, CA100, C200 e CA $\left(y=53,64+5,22 x+6,02 x^{2}+0,22 x^{3}-1,49 x^{4}+0,23\right.$ and 1,00$)$

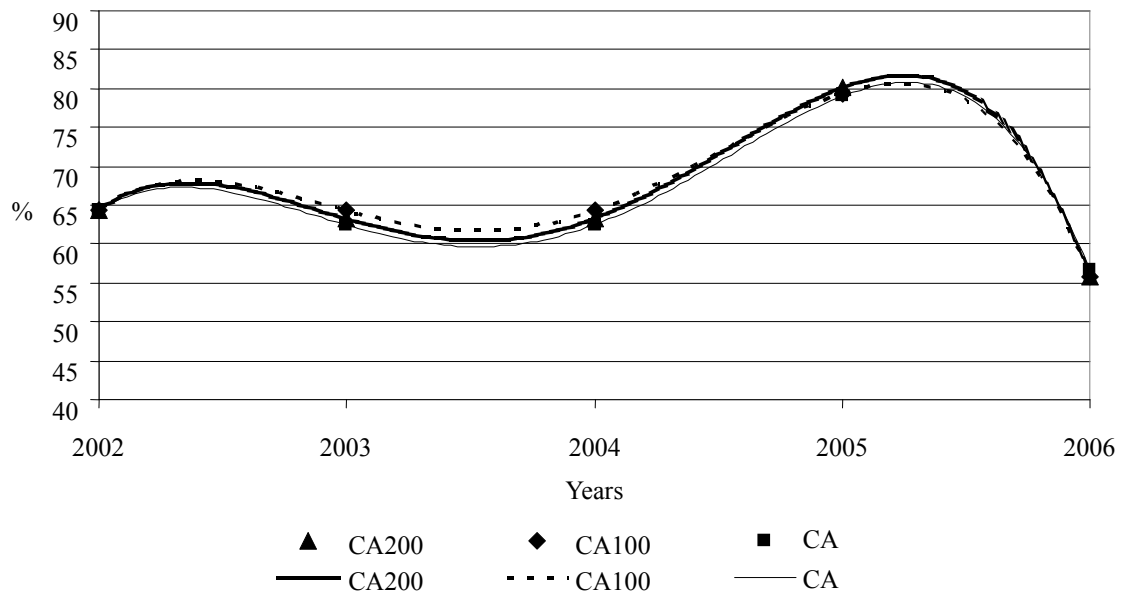

Figure 10. Dry matter in vitro digestibility of the forage of Forage peanut whole plant in mixed pasture with Coastcross, with or without nitrogen fertilization, for five years. Regression equation and $\mathrm{R}^{2}$ - CA200, CA100, $\mathrm{C} 200$ e CA $\left(y=63,34+11,45 \mathrm{x}+11,04 \mathrm{x}^{2}-3,38 \mathrm{x}^{3}-2,95 \mathrm{x}^{4}+0,18 \mathrm{e}\right.$ and 1,00$)$

In vitro digestibility of dry matter of the whole forage peanut plant (IVDP) demonstrated a quartic effect over the years and was not influenced by the treatments (Figure 10). The greatest IVDP value as well as the lowest NDF content were observed in 2005 (Figure 5), thereby indicating a negative correlation between NDF content and dry matter in vitro digestibility, which was also observed by Campos et al. (2001). The IVDP value observed in the current study was similar to those related by Ladeira et al. (2002) and Paris et al. (2009), which were 64.4\% and $63.4 \%$ respectively.

The treatments over the years significantly affected $(P<0.05)$ the average daily gain $(\mathrm{ADG})$, but there was no observed interaction between treatment and year (Figure 12). Treatments with $\mathrm{N}$ fertilization yielded greater ADG than treatments without $\mathrm{N}$ fertilization, with the exception of 2005. This fact may be due to the increase in biomass production primarily of leaf blades (Paris et al., 2008), which yielded greater ADG (Paris et al., 2009). Fagundes et al. (2011) evaluated Tifton 85 under continuous grazing and relayed a positive linear effect of N fertilization on ADG for sheep; they also reported an effect of season on pasture characteristics, which contributed to changes in animal performance.

Stocking rate (SR) had a cubic effect (Figure 13) on pasture subjected to CA200, CA100, and C200 treatments. 
Differences were not verified among these treatments $(P>0.05)$, but there was a decreasing linear effect observed over the years to CA treatment. Fagundes et al. (2011) evaluated Tifton 85 grass fertilized with different $\mathrm{N}$ levels $\left(0,100,200,300\right.$, and $\left.400 \mathrm{~kg} \mathrm{ha}^{-1}\right)$ from November to May, and concluded that $\mathrm{N}$ levels had a positive quadratic effect on stocking rate.

Stocking rate (Figure 11) showed higher values in 2002, decreasing until 2005, and then increasing in 2006. Paris et al. (2009) showed that pastures with $\mathrm{N}$ fertilization yielded the greatest values for SR. However, Yu et al. (2010) evaluated the relationship between perennial ryegrass and white clover, and observed that low nitrogen fertilization resulted in lower SR; however no changes were observed in animal performance.

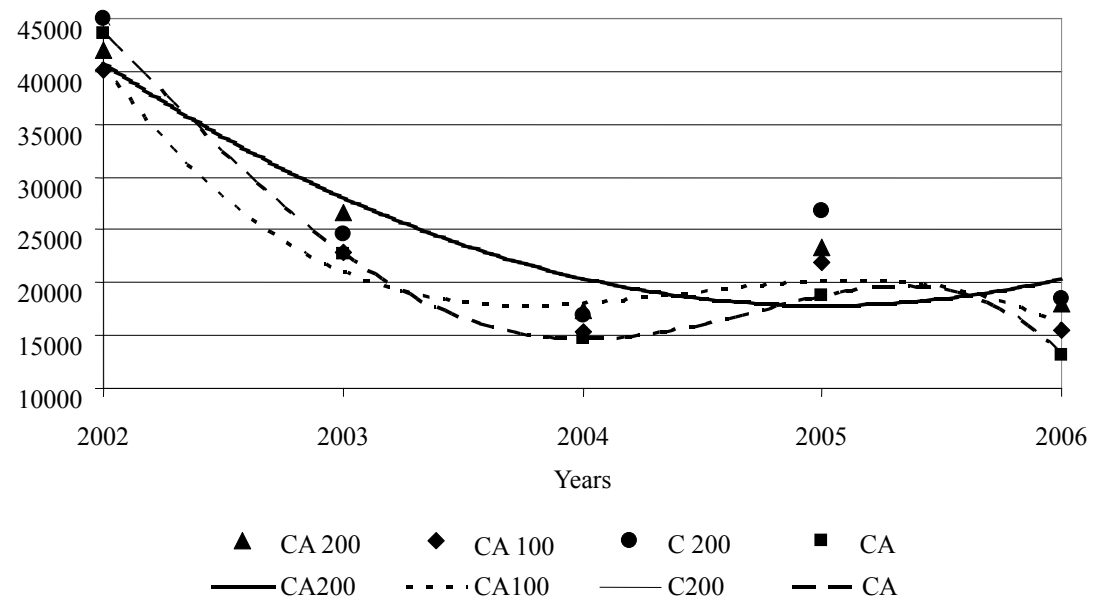

Figure 11. Forage production ( $\mathrm{kg}$ of DM ha $\mathrm{year}^{-1}$ ) in Coastcross pasture mixed with forage peanut, with or without nitrogen fertilization, for five years

Stocking rates observed in this study (between 2.5 and $5.5 \mathrm{AU}^{-1}$ over the years) are greater than the average observed in Paraná State and in Brazil, which is between 0.8 and 1.2 AU/ha. Some researchers (Prohmann et al., 2004; Paris et al., 2009) reported SR greater than those presented in this study, but these authors utilized other techniques such as irrigation and supplementation. Prohmann et al. (2004) evaluated the SR of steers fed on Coastcross grass and supplemented with soybean hulls, and found that SR ranged from 4.9 to $6.3 \mathrm{AU}^{-1}{ }^{-1}$. Meanwhile, Paris et al. (2009) evaluated the association between Coastcross and forage peanut and observed a SR ranging from 4.04 to 4.84 heifers $\mathrm{ha}^{-1}$.

Body weight gain per ha (BWG) had a decreasing linear result in all treatments (Figure 14), and differences were observed over the years $(P<0.05)$. The greatest BWG was observed in 2002, and pastures with $\mathrm{N}$ fertilization produced with the greatest BWG over the years. However, it was observed that treatments with $\mathrm{N}$ fertilization and an association between grasses and legumes were not able to maintain a similar animal performance over the years. However, a marked production decrease was observed in pastures without fertilization, while those that were fertilized with $\mathrm{N}$ had the greatest response. Therefore, $\mathrm{N}$ fertilization becomes a necessary component in pasture maintenance and in improving animal performance. Canto et al. (2009) evaluated Tanzania grass under increasing $\mathrm{N}$ levels from November to April and observed that the BWG increased linearly as a function of $\mathrm{N}$ fertilization; the results varied from 399 to $895 \mathrm{~kg} \mathrm{BW}$ per ha for treatments of 100 and $400 \mathrm{~kg}$ of N/ha, respectively. This suggests that the most important factor leading to a decrease in BWG (Figure 14) over the years was the total forage production (Figure 11); qualitative factors were constant and had little influence on this reduction.

Possibly the excessive increase in stocking rates occurred at the end of the trial period, coupled with the behavior of forage production during this period contributed to the reductions in animal performance (live weight gain per ha). 


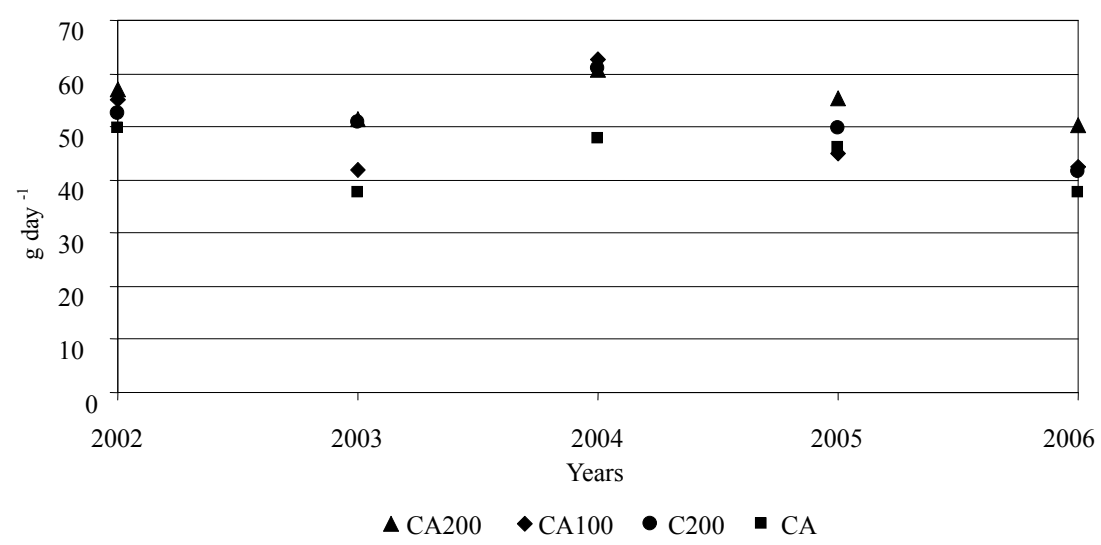

Figure 12. Average daily gain ADG $\left(\mathrm{g} \mathrm{day}^{-1}\right)$ of heifers created in Coastcross pasture mixed with Forage peanut, with or without nitrogen fertilization, for five years

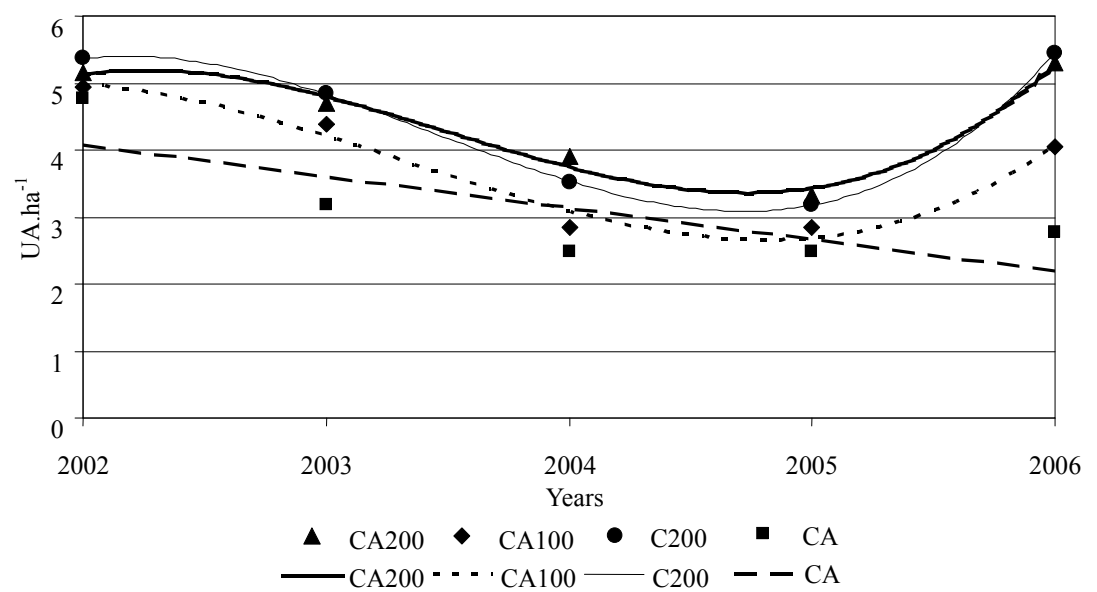

Figure 13. Stocking rate (ST) (UA/ha) of heifers created in Coastcross pasture mixed with Forage peanut, with or without nitrogen fertilization, for five years. Regression equation and $\mathrm{R}^{2}$ - CA200, CA100, C200 (y = 3,14-0,99 $\mathrm{x}+0,37 \mathrm{x}^{2}+0,23 \mathrm{x}^{3}+0,05$ and 1,00$)$ e $\mathrm{CA}(\mathrm{y}=3,87-0,56 \mathrm{x}+0,10$ and 0,86$)$

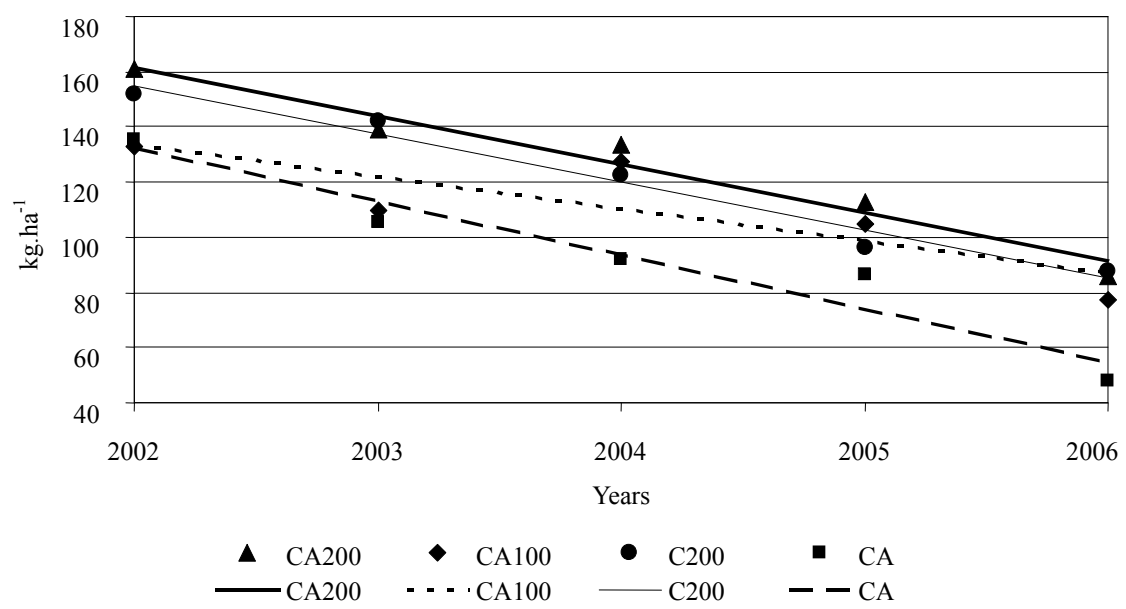

Figure 14. Body weight gain $(\mathrm{BWG})(\mathrm{kg} / \mathrm{ha})$ of heifers created in Coastcross pasture mixed with Forage peanut, with or without nitrogen fertilization, for five years. Regression equation and $\mathrm{R}^{2} \mathrm{CA} 200, \mathrm{C} 200$ e CA(y $=$

$1118,80-181,77 \mathrm{x}+27,89$ and 1,00$)$ and CA100 $(\mathrm{y}=1118,80-115,74 \mathrm{x}+48,31$ and 0,70$)$ 


\section{Conclusions}

Forage nutritional composition and animal performance vary according to the conditions each year, thereby affecting stocking rate and live weight gain. Pastures of grasses and legumes with no $\mathrm{N}$ fertilization have a lower nutritional composition than fertilized pastures mainly due to the effects of $\mathrm{CP}$. In addition, pastures without $\mathrm{N}$ fertilization have a greater decrease on forage production than those fertilized with $\mathrm{N}$. The use of cultivated and properly managed pastures leads to a greater BWG per area, which can be an excellent alternative to intensive the production of beef cattle.

\section{References}

Aroeira, L. J. M., Paciullo, D. S. C., Lopes, F. C. F., Morenz, M. J. F., Saliba, E. S., Silva, J. J., \& Ducatti, C. (2005). Disponibilidade, composição bromatológica e consumo de matéria seca em pastagem consorciada de Brachiaria decumbens com Stylosantes guianensis. Pesquisa Agropecuária Brasileira, 40(4), 413-418. http://dx.doi.org/10.1590/S0100-204X2005000400014

Association of Official Analytical Chemists (AOAC). (1990). Official methods of analysis (14th ed.). Arlington.

Barbero, L. M., Cecato, U., Lugão, S. M. B., Gomes, J. A. N., Limão, V. A., \& Basso, K. C. (2010). Produção animal e valor nutritivo da forragem de pastagem de coastcross consorciada com amendoim forrageiro. Arquivo Brasileiro de Medicina Veterinária e Zootecnia, 62(3), 645-653. http://dx.doi.org/10.1590/S0102-09352010000300021

Brâncio, P. A., Nascimento, J. D., Euclides, V. P. B., Regazzi, A. J., Almeida, R. G., Fonseca, D. M., \& Barbosa, R. A. (2002). Avaliação de três cultivares de Panicum maximum Jacq. Sob pastejo, composição química e digestibilidade da forragem. Revista Brasileira de Zootecnia, 31(4), 1605-1613. http://dx.doi.org/10.1590/S1516-35982002000700002

Campos, F. P., Sampaio, A. A. M., Vieira, P. F., \& Bose, M. L. V. (2001). Digestibilidade in vitro/gás de volumosos exclusivos ou combinados avaliados pelo resíduo remanescente da digestão da matéria seca e produção de gás. Revista Brasileira de Zootecnia, 30(5), 1579-1589. http://dx.doi.org/10.1590/S1516-35982001000600028

Canto, M. W., Bona Filho, A., Moraes, A., Hoeschl, A. R., \& Gasparino, E. (2009). Animal production in Tanzania grass swards fertilized with nitrogen. Revista Brasileira de Zootecnia, 38(7), 1176-1182. http://dx.doi.org/10.1590/S1516-35982009000700003

Corrêa, L. A., Cantarella, H., Primavesi, A. C., Primavesi, O., Freitas, A. R., \& Silva, A. G. (2007). Efeito de fontes e doses de nitrogênio na produção e qualidade da forragem de capim-coastcross. Revista Brasileira de Zootecnia, 36(4), 763-772. http://dx.doi.org/10.1590/S1516-35982007000400003

EMBRAPA. (1999). Centro Nacional de Pesquisa de Solos. Sistema brasileirode classificação de solos. Brasília.

Fagundes, J. L., Fonseca, D. M., Morais, R. V., Mistura, C., Vitor, C. M. T., Gomide, J. A., ... Lambertucci, D. M. (2006). Avaliação das características estruturais do capim-braquiária em pastagens adubadas com nitrogênio nas quatro estações do ano. Revista Brasileira de Zootecnia, 35(1), 30-37. http://dx.doi.org/10.1590/S1516-35982006000100004

Fagundes, J. L., Moreira, A. L., Freitas, A. W. P., Zonta, A., Henrich, R., Rocha, F. C., ... Vieira, J. S. (2011). Capacidade de suporte de pastagens de capim-tifton 85 adubado com nitrogênio manejadas em lotação contínua com ovinos. Revista Brasileira de Zootecnia, 40(12), 2651-2657. http://dx.doi.org/10.1590/S1516-35982011001200006

Fisher, D. S., Burns, J. C., \& Pond, R. D. (1991). Effects of grass species on grazing steers: I. Diet composition and ingestive mastication. Journal of Animal Science, 69(3), 1188-1198. Retrieved from http://www.journalofanimalscience.org/content/69/3/1188

Hejcman, M., Strnad, L., Hejcmanova, P., \& Pavlu, V. (2012). Response of plant species composition, biomass production and biomass chemical properties to high N, P and K application rates in Dactylis glomerata- and Festuca arundinacea-dominated grassland. Grass and Forage Science, 67(4), 488-506. http://dx.doi.org/10.1111/j.1365-2494.2012.00864.x

Holden, L. A. (1999). Comparison of Methods of In Vitro Dry Matter Digestibility for Ten Feeds. Journal Dairy Science, $\quad 82(8), \quad$ 1791-1794. $\quad$ Retrieved from http://www.journalofdairyscience.org/article/S0022-0302(99)75409-3/pdf

Hughes, J. C. (1976). Short-term variation in animal live weight and reduction of its effect on weighing. Animal 
Breeding Abstracts, 44, 111-118.

Instituto Agronômico do Paraná (IAPAR). (1994). Cartas climáticas do Estado do Paraná 1994. Londrina: IAPAR.

Instituto Agronômico do Paraná (IAPAR). (1999). Boletim técnico $n^{\circ} 33$. Londrina, PR.

Ladeira, M. M., Rodriguez, N. M., Borges, I., Gonçalves, L. C., Saliba, E. O. S., Brito, S. C., \& Sá, L. A. P. (2002). Avaliação do feno de Arachis pintoi utilizando o ensaio de digestibilidade in vivo. Revista Brasileira de Zootecnia, 31(6), 2350-2356. http://dx.doi.org/10.1590/S1516-35982002000900025

Mott, G. O., \& Lucas, H. L. (1952). The design, conduct and interpretation of grazing trials on cultivated and improved pastures. International Grassland Congress (Vol. 6, pp. 1380-1385). Pasadena.

Paciullo, D. S. C., Deresz, F., Lopes, F. C. F., \& Verneque, R. S. (2008). Disponibilidade de matéria seca, composição química e consumo de forragem em pastagem de capim-elefante nas estações do ano. Arquivo Brasileiro Medicina Veterinária e Zootecnia, $\quad 60(4), \quad$ 904-910. http://dx.doi.org/10.1590/S0102-09352008000400020

Paris, W., Cecato, U., Branco, A. F., Barbero, L. M., \& Galbeiro, S. (2009). Produção de novilhas de corte em pastagem de Coastcross-1 consorciada com Arachis pintoi com e sem adubação nitrogenada. Revista Brasileira de Zootecnia, 38(1), 122-129. http://dx.doi.org/10.1590/S1516-35982009000100016.

Paris, W., Cecato, U., Santos, G. T., Barbeiro, L., Avanzzo, L., \& Limão, V. (2008). Produção e qualidade de massa de forragem nos estratos da cultivar coastcross-1 consorciada com Arachis pintoi com e sem adubação nitrogenada. Acta Scientiarum Animal Science, $30(2), \quad 135-143$. http://dx.doi.org/10.4025/actascianimsci.v30i2.4676

Pitman, W. D. (2012). Bahiagrass (Paspalum notatum Flugge) management combining nitrogen fertilizer rate and defoliation frequency to enhance forage production efficiency. Grass and Forage Science, 68(3), 479-484. http://dx.doi.org/10.1111/gfs.12005

Primavesi, O., Primavesi, A. C., Corrêa, L. A., Silva, A. G., \& Cantarella, H. (2006). Lixiviação de nitrato em pastagem de Coastcross adubada com nitrogênio. Revista Brasileira de Zootecnia, 35(3), 683-690. http://dx.doi.org/10.1590/S1516-35982006000300008

Prohmann, P. E. F., Branco, A. F., Cecato, U., Jobim, C. C., Paris, W., \& Mouro, G. F. (2004). Suplementação de Bovinos em Pastagem de Coastcross (Cynodon dactylon (L.) Pers) no Verão. Revista Brasileira de Zootecnia, 33(3), 792-800. http://dx.doi.org/10.1590/S1516-35982004000300029

Rêgo, F. C. A., Damasceno, J. C., Fukumoto, N. M., Côrtes, C., Hoeshi, L., Martins, E. N., \& Cecato, U. (2006). Comportamento ingestivo de novilhos mestiços em pastagens tropicais manejadas em diferentes alturas. Revista Brasileira de Zootecnia, 35(4), 1611-1620. http://dx.doi.org/10.1590/S1516-35982006000600006

Rocha, G. P., Evangelista, A. R., Lima, J. A., \& Rosa, B. (2002). Adubação nitrogenada em gramíneas do gênero Cynodon. Revista Brasileira Ciência Animal, 3(1), 1-9.

Rocha, G. P., Evangelista, A. R., Paiva, P. C. A., Freitas, R. T. F., Souza, A. F., \& Garcia, R. (2001). Digestibilidade e fração fibrosa de três gramíneas do gênero Cynodon. Ciência e Agrotecnologia, 25(2), 396-407. http://dx.doi.org/10.4025/actasciagron.v32i2.1939

Sousa, R. S., Pires, A. J. V., Carvalho, G. G. P., Silva, F. F., Magalhães, A. F., \& Veloso, C. M. (2010). Composição química de capim-tanzânia adubado com nitrogênio e fósforo. Revista Brasileira de Zootecnia, 39(6), 1200-1205. http://dx.doi.org/10.1590/S1516-35982010000600006

Statistical Analysis Systems Institute (SAS). (2006). SAS user's guide: Statistics Version 2006. SAS, Cary, N. C.

Tilley, J. M. A., \& Terry, R. A. (1963). A two stage technique for the "in vitro" digestion of forage crop. Journal of the British Grassland Society, 18, 104-111. http://dx.doi.org/10.1111/j.1365-2494.1963.tb00335.x

Valentim, J. F., Andrade, C. M. S., Mendonça, H. A., \& Sales, M. F. (2003).Velocidade de Estabelecimento de Acessos de Amendoim Forrageiro na Amazônia Ocidental. Revista Brasileira de Zootecnia, 32(6), 1569-1577. http://dx.doi.org/10.1590/S1516-35982003000700005

Van Soest, P. J., Robertson, J. B., \& Lewis, B. A. (1991). Symposium: carbohydrate methodology, metabolism, and nutritional implications in dairy cattle. Journal Dairy Science, 74(10), 3583-3597. http://dx.doi.org/10.3168/jds.S0022-0302(05)72702-8

Viana, M. C. M., Purcino, H. M. A., \& Balieiro, G. (2000). Efeito do intervalo de corte sobre o valor nutritivo de 
Arachis pintoi. Reunião Anual da Sociedade Brasileira de Zootecnia (Vol. 37). Anais, Viçosa: SBZ. CD-ROM.

Vilela, D., Lima, J. A., Resende, J. C., \& Verquene, R. S. (2006). Desempenho de vacas da raça Holandesa em pastagem de Coastcross-1. Revista Brasileira de Zootecnia, 35(2), 555-561. http://dx.doi.org/10.1590/S1516-35982006000200031

Wang, D., Lebauer, D. S., \& Dietze, M. C. (2010). A quantitative review comparing the yield of switchgrass in monocultures and mixtures in relation to climate and management factors. Bioenergy, 2(1), 16-25. http://dx.doi.org/10.1111/j.1757-1707.2010.01035.x

Yu, Y. W., Fraser, M. D., \& Evans, J. G. (2010). Long-term effects on sward composition and animal performance of reducing fertilizer inputs to upland permanent pasture. Grass and Forage Science, 66(1), 138-151. http://dx.doi.org/10.1111/j.1365-2494.2010.00772.x

\section{Copyrights}

Copyright for this article is retained by the author(s), with first publication rights granted to the journal.

This is an open-access article distributed under the terms and conditions of the Creative Commons Attribution license (http://creativecommons.org/licenses/by/3.0/). 